\title{
ANALISIS POTENSI DAN STRATEGI PENGEMBANGAN SAPI POTONG DENGAN POLA INTEGRASI KELAPA-SAPI DI KABUPATEN HALMAHERA SELATAN PROVINSI MALUKU UTARA
}

\author{
Husnatati Rusnan*, Ch. L. Kaunang** dan Yohanis L. R. Tulung** \\ Fakultas Peternakan Universitas Sam Ratulangi , Manado, 95115
}

\begin{abstract}
ABSTRAK
Integrasi yang banyak dijumpai di Kabupaten Halmahera Selatan adalah integrasi dengan pola sapi-kelapa.Diharapkan dengan potensi luas lahan dan populasi ternak yang telah ada dan didukung oleh sumberdaya manusia maupun sumberdaya alam serta peluang pasar, pengembangan sapi potong dengan pola integrasi kelapa-sapi dapat berkembang dengan baik yang pada akhirnya akan memberikan dampak ekonomi bagi peternak yakni peningkatan kesejahteraan. Penelitian ini bertujuan menganalisis potensi dan menyusun strategi pengembangan sapi potong integrasi dengan perkebunan kelapa di Kabupaten Halmahera Selatan.Penelitian ini dilaksanakan di Kabupaten Halmahera Selatan provinsi Maluku Utara sejak bulan November 2014-Februari 2015.Penentuan responden dilakukan dengan menggunakan metode acak sederhana (simple Random Sampling). Kriteria responden yang diambil adalah petani peternak yang menjalankan pola integrasi kelapa-sapi, minimal pemeliharaan lebih dari 1 (satu) tahun dan sudah pernah menjual ternak sapi. Hasil penelitian menunjukkan karakteristik peternak sebagai berikut bermatapencarian sebagai petani, luasan kepemilikan perkebunan kelapa sebesar3,2 ha, jumlah ternak sebanyak 8,7 ekor, tingkat pendidikan rata-rata lulusan SMP, pengalaman beternak 7,9 tahun dan tujuan pemeliharaan sebagai ternak potong dan kerja. Aspek manajemen beternak yaitu Sistim pemeliharaan masih bersifat tradisional, ternak jarang terjangkit penyakit, pengetahuan peternak tentang reproduksi sangat rendah.Aspek
\end{abstract}

*Mahasiswa PPs Unsrat

**Jurusan Nutrisi dan Makanan Ternak Fakultass Peternakan Unsrat sumberdaya pakan sangat mendukung dalam pengembangan sapi potong dengan pola integrasi terutama dari nilai gizi hijauan dan kapasitas tampung.Aspek produktivitas ternak cukup baik, sedangkan sarana dan prasarana pendukung tersedia. Kesimpulan Kabupaten Halmahera Selatan memiliki potensi dalam pengembangan peternakan sapi potong dengan pola integrasi kelapa-sapi berupa sumberdaya alam, sumberdaya manusia, dukungan kebijakan pemerintah, sarana prasarana dan peluang pasar dan berdasarkan analisa potensi Kabupaten Halmahera Selatan berada pada posisi strategis sebagai wilayah pengembangan sapi potong dengan pola integrasi kelapa-sapi atau berada pada strategi pertumbuhan (growth strategy).

Kata Kunci : Sapi Potong, Kelapa, Integrasi

\section{ABSTRACT}

$\begin{array}{llr}\text { POTENTIAL } & \text { ANALYSIS } & \text { AND } \\ \text { STRATEGY DEVELOPMENT PATTERN } \\ \text { OF CATTLE } & \text { WITH INTEGRATED } \\ \text { COCONUT-COW IN SOUTH } & \text { DISTRICT } \\ \text { HALMAHERA } & \text { NORTH } & \text { MALUKU } \\ \text { PROVINCE. } & \text { Animal agricultural }\end{array}$
integration often found in South Halmahera district is the integration using coconut plantation and local beef pattern called cocobeef integration. Expected potential of land area, population of cattle supported by human and natural resources as well as market opportunities could develop coco-beef integration patterns providing the increasing economic impact for farmer welfare. This study aims to analyze the potential and development strategy of beef integration with coconut plantations in South Halmahera district. The research was conducted in South 
Halmahera district of North Maluku Province since November 2014 to February 2015. The determination of respondents was performed using simple random sampling method. Criteria of respondents involved in this study were household farmers running a coco-beef integration, at least animal maintenance of more than one year and they had sold cattle. The results showed the particular characteristics of household farmers including coconut plantation ownership of 3.2 ha with the average number of animals of 8.7 heads, the average education level of junior high school, the animal breeding experience of 7.9 years and animal maintenance purposes as beef production and animal labor. Management aspects of farm animals were still under the traditional maintenance systems, animals were resistant to disease, and house hold farmer knowledge on animal reproduction was still limited. Aspects of feed resources were positively supporting in the development of beef cattle under integration pattern, especially the nutritional value of forage and land carrying capacities. Livestock productivity aspects had quite well potential and supported facilities, including infrastructures. Therefore, it can be concluded that South Halmahera District has potential in the development of beef cattle farm applying cattle integration patterns in form of coco-beef natural resources supported by potentials of human resources, good government policy, infrastructure availability and market opportunities based on the analysis of the potential of South Halmahera district located in a strategic position as a development area of beef and coconut plantation integration patterns.

Keywords: Cattle, Coconut plantation, Integration, South Halmahera regency.

\section{PENDAHULUAN}

Penyediakan kebutuhan daging lokal tahun 2014 dibutuhkan populasi sapi mencapai 19,7 juta ekor, sementara untuk sapi potong harus tersedia sebesar 17,6 juta ekor lebih tinggi dari populasi sapi potong tahun ini sebesar 16,8 juta ekor dan subsektor peternakan diharapkan mampu memenuhi permintaan akan protein hewani yang semakin meningkat.

$$
\text { Pengembangan peternakan sapi }
$$
potong dapat dilakukan melalui integrasi ternak dan tanaman.Usaha ternak sapi dengan polai ntegrasi dapat memberikan dampak sosial budaya dan ekonomi yang positif. Sistim integrasi ini sangat menguntungkan karena ternak dapat memanfaatkan rumput dan hijauan pakan yang tumbuh liar atau limbah pertanian sebagai pakan selain itu ternak menghasilkan kotoran ternak sebagai pupuk organik untuk meningkatkan kesuburan tanah. Sistim integrasi juga dapat menambah pendapatan petani dari pembuatan kompos. Peternakan sapi rakyat yang terdapat di Kabupaten Halmahera Selatan adalah pengembangan peternakan dengan pola Integrasi Kelapa-sapi. Pemeliharaan ternak sapi dibawah pohon kelapa atau yang dikenal dengan coco beef. Pola integrasi(Integrated farming system) antara Kelapa dan sapi telah dilakukan secara turun temurun, hanya saja pemanfataan Sistim integrasi dengan pola kelapa-sapi belum termanfaatkan secara optimal.

Sektor petanian memberikan pengaruh yang cukup besar dalam perekonomian Kabupaten Halmahera Selatan. Perkebunan kelapa merupakan komoditi andalan hal ini dapat dilihat dari luas lahan yang dipakai sebagai lahan perkebunan terutama perkebunan kelapa dan peternakan sapi potong komoditi unggulan ini terlihat dari jumlah populasi ternak sapi yang ada. Halmahera Selatan memiliki potensi sumberdaya alam dan sumberdaya manusia, 
meskipun belum diketahui secara pasti daya dukungnya terhadap perkembangan sapi potong dengan pola integrasi kelapa-sapi. Potensi tersebut perlu diketahui untuk menentukan pengembangn sapi potong dengan pola integrasi kelapa sapi di Kabupaten Halmahera Selatan dimasa datang, oleh sebab itu diperlukan analisis potensi yang dapat mendukung pengembangan sapi potong dengan pola integrasi kelapa-sapi di Kabupaten Halmahera Selatan serta strategi apa yang dapat diterapkan agar perkembangan peternakan sapi potong dengan pola integrasi dapat berjalan dengan baik.

\section{PEMBAHASAN}

\section{A. Karakteristik Peternak}

Rata-rata umur peternak di Kabupaten Halmahera Selatan masih tergolong dalam usia produktif yaitu antara 15-55 tahun, tingkat pendidikan formal sebagian besar adalah lulusan Sekolah Menengah Pertama (SMP) $42,86 \%$, jika dilihat dari tingkat pendidikan peternak masih tergolong rendah. Menurut Hoda (2002), pendidikan formal merupakan indikator awal yang dapat digunakan untuk mengetahui kemampuan peternak dalam mengadopsi informasi dan inovasi baru, sebab tingkat pendidikan sangat berpengaruh terdadap perubahan pola piker, hal ini sependapat dengan Mirah dkk (2015) bahwa sumberdaya manusia merupakan faktor penting dalam pembanggunan karena pada akhirnya manusia yang menentukan berhasil atau gagalnya pembangunan suatu wilayah.
Peningkatan pengetahuan peternak dapat dilakukan melalui pendidikan informal seperti pelatihan-pelatihan.

Semua responden bermata pencarian sebagai petani dan peternak, disamping petani kelapa responden juga sebagai petani tanaman pangan guna mencukupi kebutuhan seharihari. Pengalaman peternak dalam menjalankan pola integrasi kelapa-sapi rata-rata 7.9 tahun, hal ini dikarenakan usaha yang dijalankan secara turun temurun dari orang tua, pengalaman beternak menjadi indikator keberhasilan peternak. Pengalaman beternak bisa dianggap peternak sudah lebih berpengalaman dan akan mempengaruhi cara berfikir dan pengambilan keputusan yang berhubungan dengan proses produksi.

Petani rata-rata memiliki lahan perkebunan kelapa varietas kelapa dalam yang berumur diatas 20 tahun seluas 3,2 Ha dengan jumlah kepemilikan ternak rata-rata sebanyak 8,7 ekor, jenis sapi potong yang dipelihara adalah jenis sapi bali. Tujuan pemeliharaan sebagai ternak potong dan kerja, sedangkan motivasi peternak dalam memelihara ternak yaitu sebagai tabungan masa depan dan menambah pendapatan keluarga, ini juga dikemukakan oleh Ketut (2005) yang menyatakan usaha ternak seperti ternak sapi telah banyak dikembangkan di Indonesia tetapi pada umumnya masih memelihara sebagai usaha sambilan dimana tujuannya sebagai tabungan. Karakteristik peternak tersaji pada tabel1. 
Tabel 1. Karakteristik Peternak Kabupaten Halmahera Selatan

\begin{tabular}{lc}
\hline Karakteristik & Satuan \\
\hline Rataan Umur Peternak (thn) & 44.57 \\
Tingkat Pendidikan (\%) & 1.43 \\
a. Tidak Tamat SD & 32.86 \\
b. SD & 42.86 \\
c. SMP & 22.86 \\
d. SMU - PT & 8.7 \\
Rataan Jumlah Ternak Yang Dipelihara (ekor) & 7.9 \\
Rataan Pengalaman Beternak (thn) & 100 \\
Tujuan Pemeliharaan Sebagai Ternak Potong dan Kerja (\%) & 3.2 \\
Rataan Luas Perkebunanan Kelapa (Ha) & \\
\hline
\end{tabular}

Sumber : Data Olahan (2015)

\section{Manajemen Beternak}

Manajemen beternak meliputi sistim pemeliharaan, kesehatan ternak, reproduksi dan pemanfataan limbah pertanian maupun peternakan. Pemeliharaan ternak sapi masih bersifat tradisioanal/ekstensif, sistim pemeliharaan yang dijalankan oleh peternak dengan pola integrasi kelapa-sapi adalah ternak dilepas sepanjang hari dibawah pohon kelapa, dimana ternak betina diikat dibawah pohon sedangkan pejantan dan anak dilepas pada pagi sampai siang hari dan pada sore hari ternak akan digiring berpidah tempat untuk ternak beristirahat. Pemeliharaan secara ekstensif berpeluang karena masih banyak tersedianya rumput lapangan dan hijauan lainnya yang berkualitas rendah (Elly dkk, 2013)

Keberadaan kandang sangat diperlukan dalam sistim pemeliharaan sapi potong, pada pengembalaan dengan sistim pasture fattening kandang difungsikan sebagai tempat berteduh dimalam hari atau pada waktu hari sedang panas agar produktivitas ternak dapat tercapai dengan baik dan menghidarkan ternak dari merumput terlalu pagi.

Kesehatan ternak yang dimaksud adalah jenis penyakit yang sering menyerang, pengobatan dan pencegahan penyakit serta keberadaan paramedis peternakan dan poskeswan. Ternak yang dipelihara dengan pola integrasi kelapa-sapi jarang terjangkit penyakit menular, penyakit yang sering menyerang yaitu kembung (bloat) hal ini dikarenakan ternak merumput terlalu pagi dan banyak mengkonsumsi kacang-kacangan, pengobatan dilakukan secara tradisional dengan meminumkan minyak kelapa pada ternak yang sakit. Peternak tidak pernah membawa ternak yang sakit ke poskeswan ataupun memangil paramedis peternakan, hal 
ini merupakan salah satu kelemahan dalam pengembangan peternakan sebab penanganan yang terlambat bisa menyebabkan kematian ternak. Keberadaan paramedis peternakan seperti dokter hewan atau mantri hewan dan tersedianya poskeswan disetiap kecamatankecamatan dengan potensi pengembangan sapi potong sangat diperlukan.

Pengetahuan peternak mengenai masalah reproduksi (tanda birahi, pengaturan perkawinan, tekhnologi reproduksi dan pelarangan penjualan betina produktif) masih rendah. Perkawinan ternak dilakukan secara alami adapun perkawinan secara inseminasi buatan hanya dilaksanakan pada saat program pemerintah. Apabila pengetahuan peternak tentang pencatatan (recording), gejala birahi (estrus) dan waktu tepat untuk ternak dikawinkan maka peningkatan populasi dapat tercapai melalui kelahiran ternak. Pengetahuan peternak tentang pelarangan penjualan betina produktif masih rendah, ini dikarenakan tidak adanya sosialisasi dari dinas terkait. Penjualan betina produktif dapat menurunkan populasi ternak sapi potong dan diperlukan peraturan daerah yang mendukung pelarangan pemotongan betina produktif serta pemotongan ternak harus dilakukan di Rumah Potong Hewan (RPH) untuk memudahkan pengontrolan pemotongan ternak sapi betina.

\section{Sumberdaya Pakan}

1. Produksi Hijauan Makananan Ternak dan Kualitas Pakan

Hijauan yang tersedia pada areal perkebunan kelapa terdiri dari berbagai leguminosa dan rumput -rumputan yang dapat dikonsumsi oleh ternak. Komposisi botani terdiri dari leguminosa (36\%) jenis Colopogonium dan mimosa pudica. Jenis rumput (64\%) terdiri dari rumput teki (cyperus rutundus) dan rumput lapangan. Beberapa peternak sering memberikan daun-daunan seperti kaliandra dan sesbania glandiflora.

Limbah pertanian berupa jerami jagung dan daun ubi jalar juga diberikan tetapi pemanfataan limbah ini belum termanfaatkan dengan baik. Salah satu faktor yang menentukan keberhasilan pengembangan ternak sapi yaitu ketersediaan hijauan yang cukup jumlah maupun kualitas dan berkesinambungan (Elly dkk, 2013). Menurut Siregar (2008) kelompok hijauan berkualitas tinggi yaitu campuran antara rumput dan leguminosa.

Faktor kekuatan dalam pola integrasi kelapa-sapi di Kabupaten Halmahera Selatan yaitu keberadaan kebun hijauan makanan ternak hampir berada disetiap kecamatan di Kabupaten Halmahera Selatan melalui program pemerintah. Kebun hijauan makanan ternak tersebut ditanami rumput-rumput unggul, tetapi kebun hijauan tersebut berlokasi jauh dengan areal pengembalaan ternak sehingga peternak banyak yang tidak memanfaatkan hijauan tersebut. Menurut Mirah (2015), lahan pertanian memiliki potensi sebagai bsumber pakan ternak maka perlu dilakuakan evaluasi hijauan pakan ternak untuk memprediksi potensi ternak disuatu wilayah untuk mendukung kapasitas peningkatan populasi ternak sapi.

Analisa kualitas pakan berdasarkan komposisi zat-zat makanan, kandungan protein cukup baik yakni $12,97 \%$, tingginya 
kadar protein dikarenakan hijauan yang ada dipadangan terdapat jenis kacang-kacangan.
Hasil analisa proksimat kandungan zat-zat gizi dalam hijauan terlihat pada tabel 2.

Tabel 2. Analisa komposisi Zat-Zat Hijauan Makanan Ternak Di Lokasi Penelitian

\begin{tabular}{lc}
\hline \multicolumn{1}{c}{ Uraian } & Nilai \\
\hline Kadar Air (\%) & 32,35 \\
Kadar Abu (\%) & 11,00 \\
Protein (\%) & 12,97 \\
Serat Kasar (\%) & 24,18 \\
Lemak Kasar (\%) & 4,22 \\
BETN (\%) & 47,64 \\
TDN (\%) & 63,40 \\
Energi Bruto kkal/kg & 3774,25 \\
Kalsium (\%) & 0,37 \\
Phospor (\%) & 0,38 \\
\hline Sum
\end{tabular}

Sumber : Laboratorium Nutrisi Ternak Ruminansia dan Kimia Makanan Ternak Fakultas Peternakan Universitas Padjadjaran, 2015

Berdasarkan hasil analisa diatas hijauan yang terdapat dibawah pohon kelapa tergolong kedalam kelompok hijauan dengan kualitas tinggi dikarenakan nilai protein diatas $10 \%$ dari bahan kering, energi/TDN diatas $50 \%$, sedangkan untuk kandungan kalsium (Ca) masih tergolong sedang $(0,3 \%)$ (Siregar, 2008).

Kandungan gizi didalam pakan ternak sangat penting agar ternak dapat tumbuh dan berproduksi. Menurut Parakkasi (1999) kebutuhan hijauan oleh ternak ruminan besar adalah $10 \%$ dari bobot badannya atau sekitar 20-30 kg/hari. Produktivitas ternak dapat dicapai melalui peningkatan bobot badan, ternak harus diberikan hijauan berkualitas/unggul seperti rumput gajah dan leguminosa lain seperti kaliandra. Penanaman rumput unggul dengan memanfatkan lahan diantara tanaman kelapa. Hijauan yang ditanam harus tahan injakan dan renggutan ternak serta tahan naungan dipastura (dibawah pohon kelapa).

Mata pencarian peternak yang juga petani tanaman pangan menjadikan salah satu peluang yaitu melimpahnya limbah hasil pertanian seperti jerami jagung, jerami padi ladang, limbah kedelai, dan kacang tanah yang dapat dijadikan sebagai pakan ternak. Pemanfataan limbah pertanian sebagai pakan ternak perlu sekali dilakukan untuk menjamin ketersediaan hijauan sepanjang tahun terutama pada musim kemarau atau disaat produksi hijauan menurun.

Permasalahan yang dihadapi dalam menggunakan pakan limbah pertanian dan perkebunan antara lain faktor pengetahuan peternak, kualitas limbah pertanian dan perkebunan serta faktor pencemaran, untuk mengatasi masalah tersebut diperlukannya dukungan tekhnologi dan soaialisasi tentang pemanfaatan limbah sebagai pakan ternak 
secara berkesinambungan (Indraningsih dkk, 2010). Peternak perlu diberi sentuhan tekhnologi pakan untuk pengolahan limbah pertanian menjadi pakan ternak seperti pembuatan Hay dan Silase untuk meningkat nilai gizi dari limbah hijauan tersebut.

2. Kapasitas Tampung

Keberadaan padang penggembalaan sangat diperlukan, oleh karena itu, perlu adanya upaya pemanfaatan terhadap padang penggembalaan yang ada dengan menentukan kapasitas tampung, sehingga lahan yang memproduksi hijauan makanan ternak dapat dimanfaatkan dengan optimal. Kapasitas tampung merupakan analisis kemampuan areal padang penggembalaan atau kebun rumput untuk dapat menampung sejumlah ternak, sehingga kebutuhan hijauan rumput dalam satu tahun bagi makanan ternak tersedia dengan cukup. Kapasitas tampung padang penggembalaan atau kebun rumput, erat berhubungan dengan jenis ternak, produksi hijauan rumput, musim, dan luas padang penggembalaan atau kebun rumput, oleh karena itu kapasitas tampung bisa bermacammacam dan tergantung pada pengukuran produksi hijauan rumput.

Luas lahan efektif untuk tanaman kelapa dalam satu hektar dengan jarak tanam 7 x 7 adalah 61,2 meter, dengan populasi kelapa sebanyak 204 pohon/ha.

Luasan yang tertanamn hijauan dari satu hektar perkebunan kelapa yaitu 9.938,8 meter, luasan ini dapat dipakai untuk menanam hijauan diantara pohon kelapa. Hasil penelitian menunjukkan rata-rata produksi hijauan 5,3 $\mathrm{kg} /$ cuplikan atau $2,65 \mathrm{~kg} / \mathrm{m}^{2}$ dengan kapasitas produksi 26,33 ton hijauan segar/ha. Berdasarkan data tersebut maka tiap hektar perkebunan kelapa diperoleh daya tampung ternak sebesar 2,2 ekor.

Rata - rata kepemilikan perkebunan kelapa peternak adalah 3,2 ha maka daya tampung ternaknya sebanyak 7,04 , sedangkan rata-rata kepemilikan ternak sebanyak 8,7. Berdasarkan analisa daya tampung terjadi kelebihan daya tampung pada areal pengembalaan di bawah pohon kelapa oleh petani sebesar 1,66 ekor yang berakibat pada over grazing atau kebihan merumput, dari hasil wawancara peternak mengantisipasi dengan mengembalakan ternaknya pada perkebunan kelapa kerabat yang tidak menjalankan pola integrasi sehingga kebutuhan hijauan ternak dapat tercukupi.

Menurut Rusdiana dkk (2013), Kapasitas tampung dalam 1 ha perkebunan kelapa dengan produksi hijauan segar 55 ton dan produksi rumput pangonan 45,7 ton hijauan segar mempunyai daya tampung ternak sekitar 4,1ekor ternak sapi potong dan hasil penelitian Salendu dan Elly (2012) menyatakan bahwa rumput berkualitas yang dapat diintroduksi dibawah pohon kelapa rumput Dwarft dapat menghasilkan rumput sebanyak 288 ton/tahun setara dengan 22,5 UT/tahun

Kapasitas tampung dapat ditingkatkan apabila dilakukan penanaman rumput dengan kualitas baik seperti rumput gajah sebagai tanaman sela diantara pohon kelapa dan pemberian rumput potong dari kebun Hijauan Makanan Ternak serta pemberian limbah 
pertanian sebagai pakan ternak dimanfaatkan secara optimal.

\section{Produktivitas Ternak}

Produktivitas ternak yang dimaksud adalah rata-rata bobot badan ternak berdasarkan umur dan jenis kelamin. Produktivitas ternak dipengaruhi oleh $70 \%$ faktor lingkungan dan faktor genetik sekitar 30\%. Diantara faktor lingkungan tersebut, aspek pakan mempunyai pengaruh paling besar yaitu sekitar $60 \%$, hal ini menunjukan bahwa walaupun potensi genetik ternak itu tinggi, tetapi apabila pakan kualitasnya rendah maka produktivitas yang optimal tidak akan tecapai. Elly dkk (2013) mengatakan bahwa untuk meningkatkan produktivitas ternak salah satu faktor penting yang harus diperhatikan dalah penyediaan pakan sepanjang tahun, upaya ini dilakukan agar pemenuhan kebutuhan zat makanan ternak untuk mempertahankan kehidupan pokok dan tujuan produksi dapat berkesinambungan.

Kandungan zat-zat makanan yang terdapat dalam hijauan dipakai untuk hidup pokok dan berproduksi. Protein merupakan bagian terpenting dari jaringan tubuh, apabila pakan tidak mengandung protein yang cukup tubuh ternak tidak akan membentuk dan memelihara jaringan didalam tubuh. Menurut Hoda (2002) protein yang harus tersedia dalam pakan yaitu sebesar $12 \%$ dalam bahan kering yang dipakai untuk kebutuhan hidup pokok dan pertumbuhan. Kandungan protein hijauan dilokasi penelitian adalah 12,97\%, sehingga dapat dikatakan sapi potong pada lokasi penelitian dari segi kualitas pakan telah terpenuhi kebutuhan gizinya.
Rata-rata bobot badan ternak pada lokasi penelitian berdasarkan jenis kelamin dan umur adalah sapi jantan dewasa diatas 2 tahun yaitu $320,35 \mathrm{~kg}$ dan betina $265,94 \mathrm{~kg}$, sedangkan untuk jantan anak dengan umur kurang dari 1 tahun sampai dengan 2 tahun sebesar $154.76 \mathrm{~kg}$ dan betina anak 128,27 kg.

Bobot badan sangat berkorelasi dengan pakan yang diberikan pada ternak. Kualitas hijauan dibawah pohon kelapa cukup baik dimana rumput lapangan dan leguminosa memiliki kandungan protein $12 \%$ yang cukup bagi pertumbuhan ternak. Bobot badan yang dimiliki dikategorikan cukup baik dan ini merupakan salah satu kekuatan dalam pengembangan sapi potong dengan pola integrasi kelapa-sapi.

Menurut Siregar (2008) sapi bali jantan dewasa bobot badan berkisar antara 350-400 kg, sedangkan betina berkisar 250$300 \mathrm{~kg}$. Produktivitas sapi potong (bobot badan) akan mempengaruhi nilai jual dari ternak tersebut dan efisiensi dalam penggemukan sapi potong.

\section{Sarana dan Prasarana Produksi \\ Peternakan}

Sarana dan prasarana produksi berupa kandang dan peralatan tidak dimilki oleh para peternak sebab peternak sepanjang hari mengembalakan ternaknya dibawah pohon kelapa tanpa adanya kandang, tempat pakan dan minum, pada sore hari ternak akan digiring ke sumber air (sungai) agar ternak dapat minum. Peralatan yang banyak digunakan berupa tali yang dipakai untuk menggikat induk betina, walaupun tidak 
terdapat kandang ternak pada lokasi penelitian ketersediaan sarana berupa kandang jepit hampir dimiliki disetiap desa, sehingga peternak dapat memanfaatkan kandang tersebut. Keberadaan kandang jepit ini merupakan salah satu program pemerintah daerah Kabupaten Halmahera Selatan.

Keberadaan sarana prasarana produksi seperti kandang sangat diperlukan dalam usaha peternakan, kandang akan menghindarkan ternak dari suhu yang ekstrim seperti saat musim penghujan atau saat musim kemarau, sebab kelembaban udara akan berdampak pada kesehatan ternak dan menghindarkan ternak dari pencurian.

Kabupaten Halmahera Selatan memiliki peluang untuk pengembangan sapi potong karena memiliki akses yang mudah terhadap berbagai fasilitas penunjang usaha peternakan. Akses transportasi yang sangat baik antara Kabupaten dengan Kabupaten lain atau ibu kota provinsi merupakan satu kekuatan dalam pengembangan peternakan.

\section{Kelembagaan/Fasilitas Pendukung}

Faktor kelembagaan peternak turut berpengaruh dalam kegiatan usaha ternak, dimana kelembagaan dapat menunjang keberhasilan dari usaha tersebut. Kelembagaan seperti terbentuknya kelompok tani, sebagian besar peternak merupakan anggota kelompok tani ternak. Melalui kelompok akan mempermudah dalam pengorganisasian dan mudah dalam mentrasfer ilmu pengetahuan dari anggota ke anggota, hal ini sependapat dengan Elly dkk (2013) yang menyatakan pengembangan ternak sapi potong tidak terlepas dari peranan kelompok tani ternak dan salah satu ketidak efisien sistim usaha tani tanaman ternak saat ini adalah kelembagaan usaha tani yang lemah.

Ketersediaan petugas penyuluh di setiap kecamatan telah memenuhi sehingga diharapkan pendampingan terhadap peternak dapat berjalan baik, tetapi perlu diikuti dengan peningkatan kapasitas penyuluh terutama dibidang peternakan sebab penyuluh yang tersedia sebagian besar adalah penyuluh pertanian (sarjana pertanian).

Fasilitas pendukung berupa poskeswan yang berada di ibukota Kabupaten tersedia tetapi pemanfataannya oleh petani belum optimal. Adanya beberapa bank pemerintah dan bank swasta ternama mengindikasikan perekonomian di Kabupaten Halmahera Selatan cukup kondusif. Pihak perbankan dan koperasi menyediakan dana peminjaman modal melalui kredit usaha, tetapi hampir secara keseluruhan peternak belum memanfaatkan fasilitas tersebut.

\section{Ekonomi}

1. Biaya Produksi.

Biaya produksi adalah seluruh biaya riil yang dikeluarkan petani dalam menjalankan usahanya. Berdasarkan hasil observasi dan wawancara agak sedikit mengalami kesulitan dalam menentukan biaya produksi peternakan sebab usaha yang dijalankan masih berskala rumah tangga atau skala kecil, adapaun biaya rill yang dikeluarkan adalah biaya yang dikeluarkan selama satu tahun (biaya pembelian peralatan seperti tali dan parang). Pakan dan tenaga kerja tidak dimasukkan kedalam biaya produksi sebab petani tidak membeli pakan 
(hijauan) maupun pakan tambahan dan tenaga kerja yang digunakan adalah tenaga kerja keluarga. Penggunaan sumberdaya pada usaha peternakan rakyat sulit dirinci sebab usaha ternak yang dilakukan sebagai usaha sambilan sehingga tidak ada pecurahan tenaga kerja secara khusus dan rutin untuk pemeliharaan ternak (Soekardono, 2009). Rata-rata biaya produksi yang dikeluarkan sebesar Rp. 538.571, pada perhitungan biaya produksi secara nyata tidak terdapat pengeluran non tunai dalam hal ini biaya penyusutan modal.

\section{Pendapatan Bersih}

Pendapatan merupakan selisih antara penerimaan dengan total biaya produksi, sehingga besarnya pendapatan tergantung dari besarnya out put yang dihasilkan. Pendapatan bersih yang dimaksud dalam penelitian ini adalah pendapatan tunai dari usaha tani. Untuk pendapatan peternakan diperoleh dari penjualan sapi potong, sedangkan pendapatan usaha tani kelapa diperoleh dari hasil penjualan kopra rata - rata produksi kopra pertahun dengan pola integrasi di kabupaten Halmahera Selatan yakni 1-1,2 ton/ha dengan harga jual Rp. 4.600/kg. Menurut Supandi (2006) bahwa produksi kopra dari tanaman kelapa varietas kelapa dalam yaitu 1.10 ton/thn tetapi dengan pemeliharaan secara intensif tanaman kelapa dapat menghasilkan kopra sebanyak 2.50 ton. Pendapatan bersih dari usahatani yaitu Penerimaan dari penjualan kopra setelah dikurangi dengan biaya tenaga kerja (sistim bagi hasil/penerimaan dibagi dua dengan pekerja). Pendapatan bersih dapat dilihat pada tabel 3 .

Tabel 3. Rata- Rata Pendapatan Bersih Responden Dari Usaha Tani Dan Peternakan

\begin{tabular}{ccc}
\hline Uraian & Usaha Tani & Peternakan \\
\hline Penerimaan (Rp) & 40.144 .857 & 13.692 .857 \\
Pendapatan (Rp) & 20.072 .429 & 13.154 .286 \\
\hline
\end{tabular}

Sumber : Data Olahan (2015)

Peternak menjual ternaknya dengan harga rata-rata Rp. 7.750.000/ ternak. Harga jual ini tergolong relatif kecil jika dibandingkan harga jual ketika ternak sampai di ibukota Kabupaten atau antar pulau. Pembeli datang langsung kedesa-desa sehingga biaya angkut dan biaya lain tak terduga dibebankan kepada petani. Alasan petani menjual ternaknya sangat beragam rata-rata dikarenakan adanya kebutuhan mendesak yang harus dipenuhi.
Pendapatan dari pola integrasi kelapasapi di Kabupaten Halmahera Cukup besar yakni dari tanaman kelapa diperoleh keuntungan Rp. 20.072.429 dan dari ternak sebesar Rp. 13.154.286. Hasil penelitian Rusdiana dkk (2013) bahwa hasil analisis finansial secara ekonomi dari tanaman kelapa yang belum menghasilkan (TBM) mendapatkan keuntungan dari kelapa sebesar Rp. $3.780 .000 /$ ha, sedangkan dari sapi potong 
sekitar Rp. 5.143.000 tahun, sedangkan tanaman menghasilkan (TM) mendapatkan keuntungan dari kelapa sekitar Rp. 6.750.000/ha/thn dari ternak sapi potong sekitar Rp. 1.972.000/tahun dan tanaman tidak menghasilkan atau tanaman rusak (TTM/TR) mendapatkan keuntungan dari kelapa sekitar Rp. 1.200.000/tahun sedangkan dari ternak Rp. $4.950 .000 /$ tahun

3. Kontribusi Usaha Peternakan Terhadap Total Usaha Tani

Analisis perbandingan pendapatan bersih usaha sapi potong dengan pendapatan total usahatani digunakan untuk mengetahui persentasi kontribusi pendapatan bersih usaha sapi potong terhadap pendapatan bersih petani secara keseluruhan. Secara umum nilai kontribusinya sebesar 39.6\%, hal ini menunjukkan kontribusi usaha peternakan terhadap usaha tani perkebunan kelapa cukup besar atau sumbangsih peternakan cukup besar, hal ini dikarenakan harga jual ternak tidak terpengaruh oleh krisis ekonomi dan permintaan daging sapi setiap tahun terjadi peningkatan, sedangkan harga kopra sangat fluktuatif, apabila petani hanya menjalankan usaha tani tanpa mengintegrasikan dengan sapi potong maka pendapatan yang peroleh ratarata hanya sebesar Rp.20.072.429, sedangkan apabila diintegrasi maka akan diperoleh pendapatan/tahun sebesar Rp. 33.226.715. Hasil penelitian Hoda (2002) menunjukkan nilai kontribusi usaha peternakan terhadap total usaha tani di Provinsi Maluku Utara untuk pulau besar yaitu $36,36 \%$, pulau sedang $39,93 \%$ dan pulau kecil sebesar 37\%. Fitrini dkk (2012) menunjukkan kontribusi ternak sapi terhadap pendapatan rumah tangga petani kelapa sawit sebesar 4,36 \%. Menurut Soehadji (1993) Besarnya kontribusi pendapatan peternak terhadap rumah tangga tergantung pada besar dan tujuan usaha, pada usaha peternakan yang besifat sambilan rumah tangga kontribusinya adalah $30 \%$, yang bersifat cabang usaha $30-70 \%$ dan yang bersifat usaha pokok atau industri kontribusinya sebesar 70-100\% .

Kontribusi sapi ini bisa ditingkatkan lagi apabila petani memanfaatkan hasil ternak lain seperti limbah kotoran ternak sebagai pupuk kandang untuk dijual. Ketut (2005) menambahkan pengalihan pupuk anorganik ke organik akan berdampak memacu berkembangnya sektor peternakan di Indonesia, perbaikan konisi lahan pertanian dan meningkatkan produktivitas dan pendapatan petani . Satu ekor sapi dapat menghasilkan kotoran segar sekitar 7,5 ton per tahun dan dapat diolah menjadi pupuk kandang sebanyak 5 ton.

\section{Potensi Dan Strategi Pengembangan Sapi \\ Potong Dengan Pola Integrasi Kelapa-Sapi Di Kabupaten Halmmahera Selatan}

Berdasarkan identifikasi faktor internal dan eksternal (matriks IFAS dan EFAS) dan dilanjutkan dengan analisis faktor ekternal internal sebagaimana terlihat pada gambar 1. 
Total Skor Faktor Internal

\begin{tabular}{|c|c|c|c|c|}
\hline & 4, 0 Kuat & 3,0 Rata-rata & 2,0 Lemah & 1,0 \\
\hline \multirow[t]{3}{*}{ Eksternal } & I & II & III & $\begin{array}{l}\text { Kuat } \\
3,0\end{array}$ \\
\hline & IV & $\mathrm{V}$ & VI & $\begin{array}{l}\text { Rata-rata } \\
2,0\end{array}$ \\
\hline & VII & VIII & IV & $\begin{array}{l}\text { Lemah } \\
1,0\end{array}$ \\
\hline
\end{tabular}

Gambar. 1. Hasil Analisis faktor Internal dan Eksternal

Gambar 1 memperlihatkan total hasil skor faktor eksternal menempatkan Kabupaten Halmahera Selatan dalam sel II matrik EI $(2,90$ :2,75) yang berada pada strategi pertumbuhan ini berarti usaha ternak di Kabupaten Halmahera Selatan perlu didisain untuk mencapai pertumbuhan lebih baik karena didukung oleh faktor kekuatan internal diatas rata-rata, begitu juga faktor peluang yang kuat sehingga diKabupaten Halmahera Selatan perlu dilakukan penambahan populasi ternak potong, selain itu sumberdaya manusia dalam hal ini peternak perlu diberikan sentuhan inovasi dan tekhnologi dalam membudidaya ternak secara terpadu, sumberdaya alam yang mendukung (optimalisasi penggunaan lahan) serta mengatur manajemen pemasaran sehingga dapat meningkatkan kesejahhteraan peternak

Ancaman eksternal perlu diantisipasi dengan pelarangan penjualan betina produktif dan penerapan sanksi yang jelas agar member efek jera, penggunaan ternak sebagai tenaga kerja hanya pada jantan dengan usia diatas 5 tahun serta peningkatan pengetaahuan penyuluh melalui pelatihan.

\section{KESIMPULAN DAN SARAN}

\section{Kesimpulan}

1. Kabupaten Halmahera Selatan memiliki potensi dalam pengembangan peternakan sapi potong dengan pola integrasi kelapasapi berupa sumberdaya alam, sumberdaya manusia, dukungan kebijakan pemerintah, sarana prasarana dan peluang pasar.

2. Berdasarkan analisa potensi Kabupaten Halmahera Selatan berada pada posisi strategis sebagai wilayah pengembangan pengembangan sapi potong dengan pola integrasi kelapa-sapi atau berada pada strategi pertumbuhan (growth strategy)

\section{Saran}

1. Kemampuan petani dan penyuluh perlu ditingkatkan melalui pelatihan dan penyuluhn yang intersif dan terpadu, sehingga dapat memperbaiki pola pikir dan budidaya peternakan yang baik.

2. Penanaman hijauan unggul diantara tanaman kelapa perlu dilakukan, sarana produksi ditingkatkan sehingga produktivitas ternak dapat dicapai. 
3. Perlu dibangun Rumah Potong Hewan (RPH) di Kabupaten Halmahera Selatan guna penyediaan daging aman, sehat, utuh dan halal (ASUH) dapat tercapai dan pengontorolan pemotongan betina produktif dapat terlaksana.

4. Perlu penambahan paramedis peternakan yaitu mantri hewan atau dokter hewan

5. Pos kesehatan hewan harus tersedia disetiap kecamatan agar mudah dalam akses kesehatan hewan

6. Diperlukan adanya sentuhan inivasi tekhnologi pakan, reproduksi dan pengolahan limbah peternakan.

7. Perlu dilakukaan pemetaan wilayahwilayah pengembangan sapi potong diKabupaten Halmahera Selatan

\section{DAFTAR PUSTAKA}

Elly, F. H, P. O. V. Waleleng, Ingriet D. R. Lumenta dan F. N. S. Oroh. 2013. Introduksi Makanan Ternak Sapi Di Minahasa Selatan. Joural of Tropica Forage science (Pastura) Vol 3 No $1: 5-8$. ISSN 2088-818x

Elly, F.H, Bonar M Sinaga, Sri Utami Kuncoro dan Nunung Kusnadi. 2008. Pengembangan Usaha Ternak Sapi Rakyat Melalui Integrasi Sapi Tanaman Di Sulawesi Utara.Jurnal, Litbang pertanian, 27 (2). 63-64

Elly, F.H. M.A.V. Manese dan D Polakitan. 2012 Pemberdayaan Kelompok Tani Ternak Sapi Melalui Pengembangan Hijauan Di Sulawesi Utara. Joural of Tropica Forage science (Pastura) Vol 2 No 2 : 61-65. ISSN 2088-818x
Fitrini, Ismed Iskandar Dan Surya Permana. 2012. Kontribusi Usaha Sapi Terhadap Pendapatan Anggota Kelompok Tani Suka Mulia pada Perkebunan Kelapa Sawit Rakyat. Jurnal Embrio Vol 5 No 2, Hal 85-97.

Hendra Saputra, Arief Daryanto dan Dudi S.

Hendrawan. 2009. Strategi

Pengembangan Ternak Sapi Potong

Berwawasan Agribisnis Di Propinsi Aceh. Jurnal Manajemen dan Agribisnis Volume 6 No 2.Hal 154- 156.

Hoda, A. 2002.Potensi Pengembangan Sapi Potong Pola Usaha Tani Terpadu di Wilayah Maluku Utara.Tesis.Program Pascasarjana Institut Pertanian Bogor. Bogor.

Indranigsih, R Widiastuti dan Y Sani. 2010. Limbah Pertanian Dan Perkebunan Sebagai pakan Ternak : Kendala dan Prospeknya. Lokakarya Nasional Ketersediaan IPTEK Dalam pengendalian Penyakit strategis Pada ternak Ruminansia Besar.

Ketut Kariyasa. 2005. Sistim Integrasi Tanaman-Ternak Dalam Perspektif Reorientasi Kebijakan Subsidi Pupuk dan Peningkatan Pendapatan Petani. Jurnal Analisis Kebijakan Pertanian. Vol 3 No1 : 68-80.

Mirah E Riko, E. K. M. Endoh, J. Pandey dan A. H. S Salendu. 2015. Potensi Pengembangan Ternak Sapi Pada Usaha Tani Di Kecamatan Tareran Minahasa . Jurnal Zootek Vol 35 No 1 : 46-54. ISSN 0852-2526. 
Parakkasi Aminudin. 1999. Ilmu Nutrisi Dan Makanan Ternak Ruminan. UI Press. Jakarta.

Rusdiana. S dan Cut. R Adawiyah. 2013. Analisis Ekonomi Dan Prospek Usaha Tanaman Kelapa Dan Ternak Sapi Di lahan Perkebunan Kelapa. Jurnal SEPA Vol 10 No 1, Hal 118-131. ISSN 18299946.

Salendu A.H.S dan F.H. Elly. 2012.Pemanfaatan Lahan Dibawah pohon kelapa Untuk Hijauan Pakan Sapi Di Sulawesi Utara. Joural of Tropica Forage science Vol 2 No 2 : 21-25. ISSN 2088$818 x$.

Siregar Sorry Basya.2008.Penggemukan Sapi edisi Revisi. Penebar Swadaya. Jakarta.
Soekardono. 2009. Ekonomi Agribisnis Peternakan Teori Dan Aplikasinya. Akademi Pressindo. Jakarta

Soehadji.1993. Kebijakan Pembangunan Peternakan Untuk Pengembangan Pedesaan. Makalah Yang Disampaikan Pada Lustrum VI Faterna Unad Tanggal 21 November.

Sudiarto, Bambang. 2008. Pengelolaan Limbah Peternakan Terpadu dan Agribisnis yang Berwawasan Lingkungan. Seminar Nasional Teknologi Peternakan dan Veteriner. Bandung.

Supandi dan A. Rozany Nurmanaf. 2006. Pemberdayaan Petani Kelapa Dalam Upaya Peningkatan Pendapatan. Jurnal Litbang pertanian, 25 (1). 